Jan Ryś, Ryszard Ślęczka

(Kraków)

\title{
Katedra Historii Oświaty i Wychowania Akademii Pedagogicznej im. Komisji Edukacji Narodowej w Krakowie - stan badań
}

Katedra Historii Oświaty i Wychowania prowadzi systematyczne badania naukowe, efektem których sq̨ liczne publikacje w kraju i poza jego granicami. Podejmowane są wszechstronne tematy badawcze, $\mathrm{z}$ których niektóre realizowane są przy współudziale zagranicznych ośrodków naukowych. Zespół, w skład którego obecnie wchodzą prof. dr hab. Jan Krukowski, dr Andrzej Kliś, dr Jan Ryś, dr Ryszard Ślęczka stworzył ośrodek studiów nad dziejami oświaty i myśli pedagogicznej w Polsce od XV do XX w., specjalizując się w pedeutologii, biografistyce historyczno-oświatowej, metodologii badań, współczesnej historii wychowania i pedagogice porównawczej.

Głównym tematem badawczym są „Dzieje oświaty, nauki i myśli pedagogicznej w Polsce XV-XX wieku", które zapoczątkowane zostały jeszcze przez prof. Zygmunta Rutę (wieloletniego kierownika katedry, obecnie na emeryturze) oraz nieżyjących już profesorów Czesława Majorka i Wacława Marmona.

W ramach przyjętych obszarów badawczych poszczególni pracownicy podejmowali i podejmują własne tematy szczegółowe. Prof. dr hab. Jan Krukowski wraz z prof. dr. hab. Cz. Majorkiem opracował temat: kształcenie, dokształcanie i doskonalenie nauczycieli w okresie transformacji ustrojowej. Efektem tych prac był wspólny artykuł: More than Re-Desing: Alternative Programmes of Pre-Service Teacher Education in Post-Communist Poland, w: Education and the Structuring of the European Spece. North-South, Centre-Periphery, Identity-Otherness, edited by A. M. Kazamis in collaboration with M. G. Spillane, Ateny 1998 (p. 285-298). Z tym tematem badawczym wiązała się także publikacja dr J. Krukowskiego, Przygotowanie merytoryczne pedagogów do nauczania przedmiotu: wiedza o życiu seksualnym człowieka, Edukacja, nr 2/62/1998, (s. 98-101) i książka pt.: Edukacja nauczycielska wobec zadań reformy, która ukazała się pod wspólną redakcją dr Ryszarda Ślęczki, prof. dr hab. Haliny Kosętki, dr Bożeny Pietrzyk w Krakowie w 2004 r.

W ramach zadań badawczych podejmowano liczne tematy, które zakończyły się kilkoma ciekawymi publikacjami. Dr Jan Ryś przy współudziale prof. dr. hab. Zygmunta Ruty, podjął badania zmierzające do monograficznego ujęcia dziejów najstarszej szkoły średniej w Tarnowie. Opublikowana monografia I Liceum Ogólnoksztatcqce im. Kazimierza Brodzińskiego w Tarnowie do 1939 r. (Kraków 1999, ss. 260), jest podsumowaniem dotychczasowych badań i udaną próbą ponownej interpretacji istniejących źródeł. W swych rozważaniach autorzy skoncentrowali się nie tylko na odtworzeniu $i$,zewnętrznej" charakterystyce głównych faktów z dziejów szkoły w kontekście zmian legislacyj- 
nych szkolnictwa średniego, na opisie zespołu nauczającego, czy rekonstrukcji jego dorobku dydaktycznego, ale także starali się określić funkcję społeczną I Gimnazjum w środowisku. Od lat dr A. Kliś zajmuje się dziejami szkolnictwa i myśli pedagogicznej polskiej w okresie zaborów, koncentrując się na roli nauczyciela w środowisku wiejskim Galicji. Szczególnie zainteresowało go oddziaływanie nauczycieli na kształtowanie się światopoglądu ludności wiejskiej i pozycja, jaką w tym środowisku zajmowali. Ustalenia do jakich doszedł dr A. Kliś zostały opublikowane w artykule Nauczyciel ludowy w opinii wsi galicyjskiej (Rocznik Naukowo-Dydaktyczny WSP w Krakowie, Prace z Historii Oświaty i Wychowania, t. VI, 1999, s. 39-48). Dr Jan Ryś i dr Ryszard Ślęczka podjęli badania regionalne dotyczące dziejów oświaty w Limanowej po $1945 \mathrm{r}$. Była to kontynuacja rozpoczętych wcześniej prac, w których uczestniczył jeszcze prof. dr hab. W. Marmon, a które dotyczyły okresu międzywojennego. Przygotowany tekst został zamieszczony w monografii Limanowa, t. I pod red. F. Kiryka, Kraków 1999 i t. II pod red. T Biedronia, Kraków 2002, w którym znalazło się omówienie rozwoju wszystkich typów szkół na terenie miasta, działalności instytucji kulturalno-oświatowych oraz dziejów nauczycielskiego ruchu związkowego.

Prof. dr hab. J. Krukowski w 2001 r. wydał obszerną pracę dotyczącą szkolnictwa krakowskiego w XVII w. zatytułowaną Szkolnictwo parafialne Krakowa w XVII wieku. Praca wyróżnia się solidną podstawą źródłową i wnosi wiele nowych ustaleń do dziejów szkolnictwa staropolskiego.

W 2003 r. dr Ryszard Ślęczka zakończył kilkuletnie badania nad szkolnictwem zawodowym. Drukiem ukazała się pt. Szkolnictwo zawodowe Krakowa w latach 1945-1961. Praca jest nowym spojrzeniem na rozwój szkolnictwa zawodowego w Krakowie, w kontekście przemian politycznych, gospodarczych i społecznych.

Dr Andrzej Kliś brał udział w pracach zespołu naukowego kierowanego przez prof. dr hab. Danutę Dryndę, który opracował i wydał podręcznik Historia wychowania (Warszawa 2006).

Od kilku lat dr Jan Ryś prowadzi badania w zakresie dziejów wychowania i szkolnictwa wojskowego w okresie staropolskim, w kontekście przemian w szkolnictwie europejskim. Na obecnym etapie badań przygotowywana jest rozprawa zawierająca szczegółową analizę różnych projektów i koncepcji wychowania oraz szkolenia wojskowego.

Ważnym nurtem w badaniach prowadzonych przez pracowników Katedry jest wspomniana już biografistyka historyczno-oświatowa. W tej dziedzinie podjęta została współpraca z Pracownią Biografistyki Instytutu Historii Akademii Pedagogicznej w Krakowie. Zaowocowała ona kilkoma udanymi opracowaniami, takimi jak: Szkolny słownik biograficzny (1999), trzema tomami biografistyki do Wielkiej Historii Polski (Kraków 1997-2001), oraz dwutomowym słownikiem Slownik biograficzny historii Polski (wyd. Ossolineum 2005). Należy w tym miejscu wspomnieć o przedsięwzięciu, w które zaangażowane było środowisko naukowe Krakowa - o Encyklopedii Krakowa (Kraków, 2000). Pracownicy Katedry opracowali tu znaczną część haseł przedmiotowych dotyczących nauki, oświaty i szkolnictwa oraz hasła biograficzne. Prof. dr hab. J. Krukowski redagował jeden z głównych działów: Nauka, oświata, szkolnictwo i wojskowość. Pracownicy Katedry mieli także swój udział w opracowaniu Stownika polskich pedagogów, pod red. W. Bobrowskiej-Nowak i Danuty Dryndy. 
W ramach własnych inicjatyw badawczych pracownicy podejmują szereg tematów na rzecz uczelni i środowiska. W wyniku tych prac powstało jubileuszowe wydawnictwo pt.: Państwowe Pedagogium, Państwowa Kyższa Szkoła Pedagogiczna, Akademia Pedagogiczna im. Komisji Edukacji Narodowej w Krakowie, Kraków 2006, ss. 167 autorstwa prof. dr. hab. J. Krukowskiego. Obszerne kilkusetstronicowe opracowanie jest ilustrowaną historią Państwowego Pedagogium w Krakowie, następnie Wyższej Szkoły Pedagogiczne, obecnie Akademii Pedagogicznej w Krakowie.

W minionym okresie pracownicy Katedry uczestniczyli w opracowaniu Wielkiej historii Polski (wyd. Pinex, Kraków 1997-2000), przygotowywanej pod redakcją naukową prof. dr hab. Feliksa Kiryka. W tym piętnastotomowym opracowaniu dr J. Ryś opracował czasy jagiellońskie (t. II, Kraków 1997, s. 103-279, t. III, Kraków 1999, ss. 280), a wspólnie $\mathrm{z}$ dr hab. W. Marmonem, przygotowali okres popowstaniowy 1864-1918 (t. VII, Kraków 1999, s. 85-249, t. VIII, Kraków 1999, ss. 286). Opracowanie to jest najnowszą syntezą dziejów Polski. Pomyślane było też jako podręcznik, stąd wyróżnia się niespotykanym dotychczas rozwiązaniem metodycznym. Uzupełnieniem dziejów politycznych, gospodarczych i kulturowych są wspomniane już trzy tomy biografistyki, prezentujące ważniejsze postacie z przeszłości Polski (t. XI-XIII, Kraków 2000).

Zestawiając przedsięwzięcia badawcze podejmowane przez pracowników Katedry w ostatnim okresie, wymienić należy blisko 49 opublikowanych prac, w tym 15 w językach obcych. Pracownicy byli autorami lub współautorami 9 książek. W tym miejscu wymienić należy jedno z ważniejszych wydawnictw przygotowywane przez pracowników Katedry, do wspóltworzenia którego zaproszono całe środowisko polskich historyków wychowania. Pod redakcją Zygmunta Ruty i Ryszarda Ślęczki wyszła książka zatytułowana $W$ stużbie szkoly i nauki. Księga poświęcona profesorowi Czestawowi Majorkowi (Kraków 2003, ss. 329), w której ukazano metodologiczne problemy historii wychowania i dydaktyki historii, problematykę z dziejów szkolnictwa i pozaszkolnej edukacji dorosłych, badania nad przeszłością Uniwersytetu Jagiellońskiego, dziejami wychowania w rodzinie oraz badania nad biografią edukacyjną.

Katedra prowadzi ożywioną współpracę naukową z ośrodkami badawczymi, głównie w USA, Kanadzie i Japonii. Wspótpraca ta przejawia się wymianą studentów i kadry naukowej oraz realizacją wspólnych badań naukowych. W ramach wymiany w $1999 \mathrm{r}$. w Katedrze gościł prof. W. Urban z Uniwersytetu Georgia USA, który prowadził z naszymi studentami zajęcia konwersatoryjne. Od kilku lat systematycznie Katedrę odwiedza prof. K. Mazurek z Uniwersytetu w Lethebridge w Kanadzie. W 2006 r. podjęta została współpraca z prof. Shunji Tanabe z Uniwersytetu w Kanazawa, której przedmiotem będzie analiza porównawcza form kształcenia nauczycielskiego obu krajów. Udział w międzynarodowym życiu naukowym i kontakty $\mathrm{z}$ innymi ośrodkami naukowymi przejawiają się także aktywnym uczestnictwem w międzynarodowych konferencjach. Pracownicy Katedry są członkami prestiżowych międzynarodowych organizacji historyków edukacji, dydaktyków historii i pedagogiki porównawczej.

Nowym kierunkiem badań rozpoczętym przed kilku laty jest szeroko rozumiana edukacja europejska. Prowadzone są prace nad stanem oświaty w krajach członkowskich Unii Europejskiej. Analizie badawczej poddawane są kierunki zmian w systemach oświatowych oraz nowe tendencje w badaniach pedagogicznych. Od $2002 \mathrm{r}$. w Katedrze realizowany jest grant 
z fundacji Jeana Moneta „History of Educational unity: developments and practical issues”. Ma on formę wykładu kursowego. Początkowo wykład prowadzony był na jednym kierunku, a obecnie na wszystkich kierunkach pedagogicznych pod nazwą edukacja europejska. Pierwszym kierownikiem grantu był prof. dr hab. Czesław Majorek, obecnie jest nim dr Jan Ryś.

Od kilku lat współpracujemy z Komisją Nauk Pedagogicznych PAN Oddział w Krakowie, prof. Z. Ruta jest redaktorem Rocznika Komisji Nauk Pedagogicznych, a prof. J. Krukowski od ponad 20 lat sekretarzem Redakcji. Obecność Katedry w polskim życiu naukowym zaznaczyła się w ostatnim czasie także udziałem w powołaniu do życia Towarzystwa Historyków Edukacji. Należy tu wspomnieć, że Katedra wspiera działalność THE i jest organizatorem ogólnopolskiego konkursu na prace magisterskie $\mathrm{z}$ historii edukacji. Od kilku lat wydaje własny rocznik naukowy „Prace z Historii Oświaty i Wychowania". 